\title{
Adsorption Mechanism of Gallium(III) and Indium(III) onto $\gamma-\mathrm{Al}_{2} \mathrm{O}_{3}$
}

\author{
Cheng-Fang Lin, ${ }^{* 1}$ Kuen-Sen Chang, $†$ Chia-Wen Tsay, $*$ Dar-Yuan Lee, $\ddagger$ \\ SHANG-LiEN LO, $*$ AND TATSUYA YASUNAGA $*, 2$ \\ *Graduate Institute of Environmental Engineering, National Taiwan University, Taipei, Taiwan, 106; †Department of Environmental Engineering, \\ National Lien-Ho College of Technology and Commerce, Miao-Li, Taiwan, 360; and $\$$ Graduate Institute of Agricultural Chemistry, \\ National Taiwan University, Taipei, Taiwan, 106
}

Received September 30, 1996; accepted December 12, 1996

\begin{abstract}
The adsorption mechanism of trivalent $\mathrm{Ga}$ and In onto $\gamma-\mathrm{Al}_{2} \mathrm{O}_{3}$ was investigated using a triple-layer model simulation and pressure-jump technique. Bidentate $\mathrm{Ga}^{3+}$ and $\mathrm{In}^{3+}$ and monodentate $\mathrm{GaOH}^{2+} / / \mathrm{InOH}^{2+}$ are the most likely surface species responsible for $\mathrm{Ga}$ (III)/In (III) adsorption. Sorption of Ga(III) and In (III) can be interpreted as an associative process. The adsorption pathway is a two-step mechanism: proton release from surface hydroxyl group (s) followed by coordination of $\mathrm{Ga}$ (III)/In(III) species to the depronated site(s). Intrinsic adsorption rate constants cannot be estimated with a liner free-energy relationship between the adsorption rate constant and the rate of water exchange, which is developed solely based on the dissociative sorption mechanism of divalent ions. 1997 A cademic Press
\end{abstract}

Key Words: $\mathrm{Ga}(\mathrm{III}) ; \ln (\mathrm{III}) ; \gamma-\mathrm{Al}_{2} \mathrm{O}_{3}$; adsorption; water exchange rate; linear free energy; intrinsic adsorption rate constants.

\section{INTRODUCTION}

The transport of heavy metals in the aquatic environment has long been the primary interest of environmental engineers and geochemists. Several studies have reported that the fate and the concentration distribution of metal ions are primarily regulated via adsorption/desorption at the surface of minerals such as $\mathrm{Fe}$ and/or $\mathrm{Al}$ oxides and hydroxides (1, 2 ). The surface complexation model by Stumm et al. (3) and the triple layer model (TLM) of Leckie and his colleagues $(4,5)$ have been successfully used to interpret the interactions of metal ions and minerals qualitatively and quantitatively. These two models may address the thermodynamic equilibrium of the interfacial phenomena, but they are not able to reveal the mechanistic pathways of the reactions.

The pressure-jump technique has been used to better understand the kinetic aspect of metal adsorption onto minerals. For example, Hachiya et al. $(6,7)$ employed this approach to investigate the reaction mechanisms of divalent $\mathrm{Pb}, \mathrm{Zn}$, $\mathrm{Cu}, \mathrm{Co}$, and $\mathrm{Mn}$ adsorption at the water/oxide interface, while Hayes and Leckie (5) studied the mechanism of $\mathrm{Pb}$

\footnotetext{
${ }^{1}$ To whom correspondence should be addressed.

${ }^{2}$ Visiting scholar.
}

sorption onto goethite. Zhang and Sparks further (8-10) examined the sorption mechanisms of anions at the water/ goethite interface. The results of these works have indicated that inner-sphere surface complexes are formed between the divalent ions and oxide surface hydroxyl sites. The sorption pathways are postulated as a two-step mechanism with a metal ion attached first, followed by the release of a proton from the surface hydroxyl group. Furthermore, the intrinsic adsorption rate constants of divalent metal ions obtained from pressure-jump kinetic experiments are closely related to the water exchange rate of metal ions. Hence, the intrinsic adsorption rate constants can be calculated from the water exchange rate of the aquo metal ions based on the linear free-energy relationship (LFER) of Hachiya (7). Other investigators $(11,12)$, however, report that the sorption mechanism of $\mathrm{Cr}$ (III) exhibits different reaction steps from those postulated by Hachiya and Hayes. The intrinsic adsorption rate constants determined by Wehril et al. and Chang et al. cannot be predicted by the LFER. Consequently, this study was undertaken to further explore the sorption mechanism( $\mathrm{s}$ ) of trivalent metal ions and evaluate the plausibility of the LEFR on calculating intrinsic adsorption rate constants. $\mathrm{Ga}$ (III) and In(III) were used as model ions for kinetic investigation of their adsorption onto $\gamma-\mathrm{Al}_{2} \mathrm{O}_{3}$ using the pressure-jump technique.

\section{MATERIALS AND METHODS}

\section{Materials}

Reagent analytical grade $\mathrm{Ga}\left(\mathrm{NO}_{3}\right)_{3}$ and $\mathrm{In}\left(\mathrm{NO}_{3}\right)_{3} \cdot 3 \mathrm{H}_{2} \mathrm{O}$ were obtained from Strem Chemicals of USA and Nacalai Tesque of Japan, respectively. The $0.01 M$ stock solutions of Ga(III) and In(III) were prepared with MilliQ water and the solution was acidified to $\mathrm{pH} 1.2$ to ensure no polymerization. The $\gamma-\mathrm{Al}_{2} \mathrm{O}_{3}$ obtained from Aerosil Co. (Japan) was prewashed with $0.1 M \mathrm{NaOH}$, according to the procedure described by Hohl and Stumm (13). After the prewash, the $\gamma-\mathrm{Al}_{2} \mathrm{O}_{3}$ was rinsed with deionized water and dialyzed before use in adsorption experiments. 
(I) Surface protolysis reactions

$\mathrm{SOH}_{2}^{+}=\mathrm{SOH}+\mathrm{H}^{+}$

$\mathrm{SOH}=\mathrm{SO}^{-}+\mathrm{H}^{+}$

(II) Electrolyte surface reactions

$\mathrm{SOH}+\mathrm{Na}^{+}=\mathrm{SO}^{-}-\mathrm{Na}^{+}+\mathrm{H}^{+}$

$\mathrm{SOH}+\mathrm{H}^{+}+\mathrm{NO}_{3}^{-}=\mathrm{SOH}_{2}^{+}-\mathrm{NO}_{3}^{-}$

(III) Outer-sphere surface reactions

$\mathrm{SOH}+\mathrm{Me}^{3+}=\mathrm{SO}^{-}-\mathrm{Me}^{3+}+\mathrm{H}^{+}$

$\mathrm{SOH}+\mathrm{Me}^{3+}+\mathrm{H}_{2} \mathrm{O}=\mathrm{SO}^{-}-\mathrm{MeOH}^{2+}+2 \mathrm{H}^{+}$

(IV) Inner-sphere surface reactions

$\mathrm{SOH}+\mathrm{Me}^{3+}=\mathrm{SOMe}^{2+}+\mathrm{H}^{+}$

$2 \mathrm{SOH}+\mathrm{Me}^{3+}=(\mathrm{SO})_{2} \mathrm{Me}^{2+}+2 \mathrm{H}^{+}$

$\mathrm{SOH}+\mathrm{Me}^{3+}+\mathrm{H}_{2} \mathrm{O}=\mathrm{SOMeOH}^{+}+2 \mathrm{H}^{+}$

$2 \mathrm{SOH}+\mathrm{Me}^{3+}+\mathrm{H}_{2} \mathrm{O}=(\mathrm{SO})_{2} \mathrm{MeOH}+3 \mathrm{H}^{+}$

$$
\begin{gathered}
K_{\mathrm{a} 1}^{\mathrm{int}}=\frac{\overline{[\mathrm{SOH}]} \overline{\left[\mathrm{H}^{+}\right]}}{\overline{\left[\mathrm{SOH}_{2}^{+}\right]}} \exp \left(\frac{-\psi_{0} F}{R T}\right)=10^{-7.2} \\
K_{\mathrm{a} 2}^{\mathrm{int}}=\frac{\overline{\left[\mathrm{SO}^{-}\right]} \overline{\left[\mathrm{H}^{+}\right]}}{\overline{[\mathrm{SOH}]}} \exp \left(\frac{-\psi_{0} F}{R T}\right)=10^{-9.5}
\end{gathered}
$$

$$
\begin{gathered}
K_{\mathrm{Na}^{+}}^{\mathrm{int}_{+}}=\frac{\overline{\left[\mathrm{SO}^{-}-\mathrm{Na}^{+}\right]} \overline{\left[\mathrm{H}^{+}\right]}}{\overline{[\mathrm{SOH}]} \overline{\left[\mathrm{Na}^{+}\right]}} \exp \left(\frac{\left(\psi_{\beta}-\psi_{0}\right) F}{R T}\right)=10^{-9.1} \\
K_{\mathrm{NO}_{3}}^{\mathrm{int}}=\frac{\overline{\left[\mathrm{SOH}_{2}^{+}-\mathrm{NO}_{3}^{-}\right]}}{\overline{[\mathrm{SOH}]} \overline{\left[\mathrm{H}^{+}\right]} \overline{\left[\mathrm{NO}_{3}^{-}\right]}} \exp \left[\frac{\left.\psi_{0}-\psi_{\beta}\right) F}{R T}\right]=10^{-8.7}
\end{gathered}
$$

$$
\begin{aligned}
& K_{\mathrm{Me}}^{\mathrm{int}}=\frac{\overline{\left[\mathrm{SO}^{-}-\mathrm{Me}^{3+}\right]} \overline{\left[\mathrm{H}^{+}\right]}}{\overline{[\mathrm{SOH}]} \overline{\left[\mathrm{Me}^{3+}\right]}} \exp \left[\frac{\left.3 \psi_{\beta}-\psi_{0}\right) F}{R T}\right] \\
& K_{\mathrm{Me}}^{\mathrm{int}}=\frac{\overline{\left[\mathrm{SO}^{-}-\mathrm{MeOH}^{2+}\right]} \overline{\left[\mathrm{H}^{+}\right]^{2}}}{\overline{[\mathrm{SOH}]} \overline{\left[\mathrm{Me}^{3+}\right]}} \exp \left[\frac{\left(2 \psi_{\beta}-\psi_{0}\right) F}{R T}\right]
\end{aligned}
$$

$$
\begin{gathered}
* K_{\mathrm{Me}_{1}}^{\mathrm{int}}=\frac{\overline{\left[\mathrm{SOMe}^{2+}\right]} \overline{\left[\mathrm{H}^{+}\right]}}{\overline{[\mathrm{SOH}]} \overline{\left[\mathrm{Me}^{3+}\right]}} \exp \left(\frac{2 \psi_{0} F}{R T}\right) \\
* K_{\mathrm{Me}_{2}}^{\mathrm{int}}=\frac{\left[(\mathrm{SO})_{2} \mathrm{Me}^{2+}\right] \overline{\left[\mathrm{H}^{+}\right]^{2}}}{\overline{[\mathrm{SOH}]^{2}} \overline{\left[\mathrm{Me}^{3+}\right]}} \exp \left(\frac{\psi_{0} F}{R T}\right) \\
* K_{\mathrm{MeOH}_{1}}^{\mathrm{int}}=\frac{\overline{[\mathrm{SOMeOH}]} \overline{\left[\mathrm{H}^{+}\right]^{2}}}{\overline{[\mathrm{SOH}]} \overline{\left[\mathrm{Me}^{3+}\right]}} \exp \left(\frac{\psi_{0} F}{R T}\right) \\
* K_{\mathrm{MeOH}_{2}}^{\mathrm{int}}=\frac{\left[(\mathrm{SO})_{2} \mathrm{MeOH}^{2} \overline{\left[\mathrm{H}^{+}\right]^{3}}\right.}{\overline{[\mathrm{SOH}]^{2}} \overline{\left[\mathrm{Me}^{3+}\right]}}
\end{gathered}
$$

Note. Me stands for Ga or In.

\section{Sorption Experiments}

In batch adsorption experiments, the system contained 3 $\times 10^{-3} M$ total $\mathrm{Ga}(\mathrm{III})$ or $\mathrm{In}(\mathrm{III})$ and $40 \mathrm{~g} \mathrm{dm}^{-3}$ of $\gamma$ $\mathrm{Al}_{2} \mathrm{O}_{3}$. The background electrolyte concentrations of the suspensions were adjusted to $0.01,0.05$, and $0.1 M$ using $\mathrm{NaNO}_{3}$. The $\mathrm{pH}$ of suspension was adjusted with a small amount of $\mathrm{HNO}_{3}$ or $\mathrm{NaOH}$ to cover the range from $\mathrm{pH} 1.5$ to 3.5 ( $\mathrm{Ga}$ (III) system) or from $\mathrm{pH} 2.5$ to 4.0 (In(III) system). At each adjusted $\mathrm{pH}$ point, a $10 \mathrm{ml}$ aliquot of suspension was transferred to a polypropylene tube under an $\mathrm{N}_{2}$ atmosphere. Samples were kept at $25 \pm 0.1^{\circ} \mathrm{C}$ and subjected to shaking for 12 days to ensure that equilibrium was achieved. At the end of the equilibrium period, each suspen- sion $\mathrm{pH}$ was determined and the solid and liquid were separated by filtration $(0.2 \mu \mathrm{m}$, Millipore $)$. Filtrates were acidified for subsequent $\mathrm{Ga}$ or In analysis using inductively coupled plasma (Jobin Yvon JY-24).

\section{Kinetic Measurements}

The pressure-jump apparatus was used for mechanistic investigation of $\mathrm{Ga}(\mathrm{III}) /$ or $\mathrm{In}(\mathrm{III}) / \gamma-\mathrm{Al}_{2} \mathrm{O}_{3}$ interactions. The samples prepared in batch equilibrium experiments after $\mathrm{pH}$ measurement were saved for pressure-jump usages. The temperature of the sample cell and reference cell was maintained at $25 \pm 0.1^{\circ} \mathrm{C}$. The pressure-jump apparatus equipped with an electrical conductivity detector was similar to that 


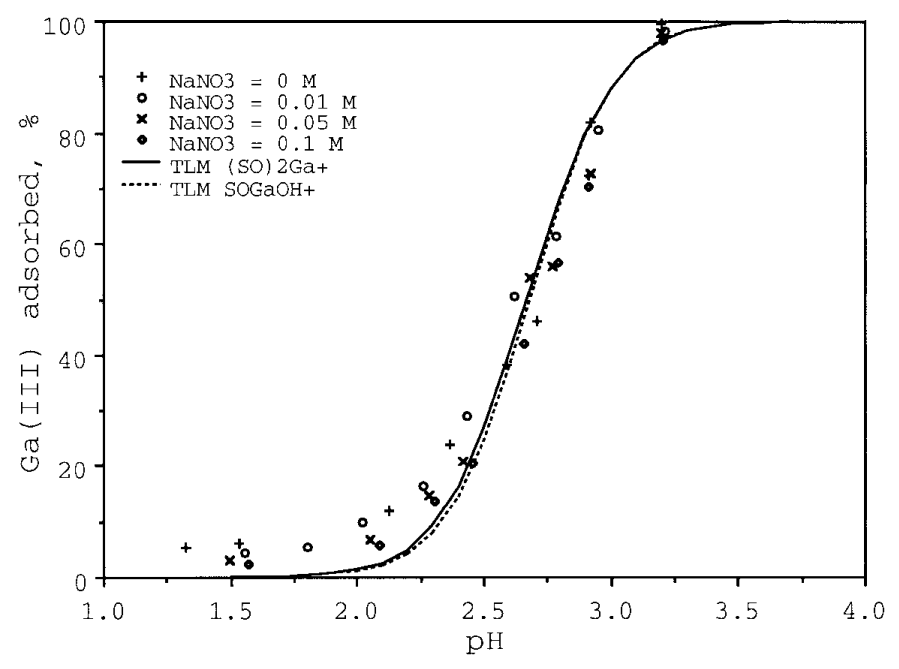

FIG. 1. Adsorption of $\mathrm{Ga}$ (III) onto $\gamma-\mathrm{Al}_{2} \mathrm{O}_{3}$ as a function of $\mathrm{pH}$ under various background $\mathrm{NaNO}_{3}$ concentrations. Solid line denotes TLM results with no $\mathrm{NaNO}_{3}$ addition using bidentate $(\mathrm{SO})_{2} \mathrm{Ga}^{+}$of Eq. [8]. Dotted line represents simulation of monodentate $\mathrm{SOGaOH}^{+}$using Eq. [9]. Symbols denote experimental data.

previously used by Hachiya et al. (7). It consisted of a pressure chamber (Photo High Pressure Inc., Japan), a Wheatstone bridge circuit (Sea Land Electr. Wave Inc., Japan), and a digital storage oscilloscope (TEK 2224). During the pressure-jump relaxation measurement, the equilibrium state of the $\mathrm{Ga}(\mathrm{III}) /$ or $\mathrm{In}(\mathrm{III}) / \gamma-\mathrm{Al}_{2} \mathrm{O}_{3}$ system was perturbed by raising the system pressure to approximately 100 $\mathrm{atm}$. The pressure was controlled to return to ambient conditions within $100 \mu \mathrm{s}$. At the moment of pressure change, the oscilloscope was triggered to record the changes in system conductivity. The signals recorded by the oscilloscope were digitized and analyzed by a linear regression technique for calculating the reciprocal relaxation time $\left(\tau^{-1}\right)$.

\section{Model Analysis}

The TLM of Hayes and Leckie (5) was used to simulate the equilibrium distribution of background electrolyte ions and $\mathrm{Ga}(\mathrm{III})$ or $\mathrm{In}(\mathrm{III})$ species at the $\gamma-\mathrm{Al}_{2} \mathrm{O}_{3} /$ water interface. The TLM reactions and expression for intrinsic reaction constants are summarized in Table 1. Part I (Eqs. [1] and [2]) of Table 1 describes protonation of reacting surface sites and Part II (Eqs. [3] and [4]) the formation of complexes between the background electrolyte ions and the surface. Based on our recent work (12), the interactions of $\mathrm{Ga}(\mathrm{III}) / \mathrm{In}(\mathrm{III})$ on the surface of $\gamma-\mathrm{Al}_{2} \mathrm{O}_{3}$ are assumed to be those shown in Parts III and IV of Table 1. Ion-pair formation at the $\beta$-plane (Eqs. [5] and [6]) occurs if $\mathrm{Ga}^{3+}$ / $\mathrm{In}^{3+}$ ion or $\mathrm{Ga}(\mathrm{III}) / \mathrm{In}$ (III) hydrolytic complex reacts with $\mathrm{SOH}$ similarly to a background electrolyte. If adsorption of $\mathrm{Ga}^{3+} / \mathrm{In}^{3+}$ or $\mathrm{Ga}(\mathrm{III}) / \mathrm{IN}$ (III) complex is visualized as a chemically specific reaction, the reaction can be expressed as an inner-sphere surface coordination process (Eqs. [7]-
[10]). The equilibrium and mass balance equations are solved simultaneously in the TLM. The specific surface area of $\gamma-\mathrm{Al}_{2} \mathrm{O}_{3}$ is $100 \mathrm{~m}^{2} / \mathrm{g}$, according to the manufacturer. Site density was reported by Peri (14) to be 8 sites $/ \mathrm{nm}^{2}$. Innerand outer-plane capacitances were assumed to be 80 and 20 $\mu \mathrm{F} / \mathrm{cm}^{2}$, respectively (15). The above parameters were used in the model analysis to best fit intrinsic constants for the $\mathrm{Ga}(\mathrm{III}) /$ or $\mathrm{In}(\mathrm{III}) / \gamma-\mathrm{Al}_{2} \mathrm{O}_{3}$ reaction.

\section{RESULTS AND DISCUSSION}

\section{Equilibrium Adsorption}

Adsorption of $\mathrm{Ga}(\mathrm{III})$ and $\mathrm{In}(\mathrm{III})$ onto $\gamma-\mathrm{Al}_{2} \mathrm{O}_{3}$ under various $\mathrm{NaNO}_{3}$ concentrations are presented in Figs. 1 and 2 , respectively. The effect of background electrolyte concentration on the adsorption of $\mathrm{Ga}$ (III) and In(III) is insignificant. The $\mathrm{pH}$-adsorption patterns of $\mathrm{Ga}$ (III) and $\mathrm{In}$ (III) are similar to those of other divalent and trivalent ions. Sorption of $\mathrm{Ga}$ (III) changes from a negligible amount at $\mathrm{pH} 1.5$ to nearly total removal at $\mathrm{pH} 3.0$, and the sorption of $\mathrm{In}$ (III) covers the range of $\mathrm{pH} 2.8$ to 4.0. Thus, the range of $\mathrm{pH}-$ adsorption curves of trivalent metal ions is different from those of divalent metal ions; the trivalent ions are toward the acidic pHs while divalent ions are near the neutral $\mathrm{pHs}$. Specifically, the trend is closely correlated to the first hydrolysis constant $\left(K_{1}^{*}\right)$ of trivalent ions. The lower the $\mathrm{p} K_{1}^{*}$ value, the adsorption curve is more toward the acidic pHs. Table 2 lists the $\mathrm{p} K_{1}^{*}$ values and $\mathrm{pH}$ ranges of the adsorption curves of $\mathrm{Ga}(\mathrm{III})$, In(III), and $\mathrm{Cr}$ (III).

The formation of the outer-sphere complex of $\mathrm{Ga}(\mathrm{III})$ or In(III) as proposed in Eqs. [5] and [6] was ruled out as the TLM simulations were unable to match the measured

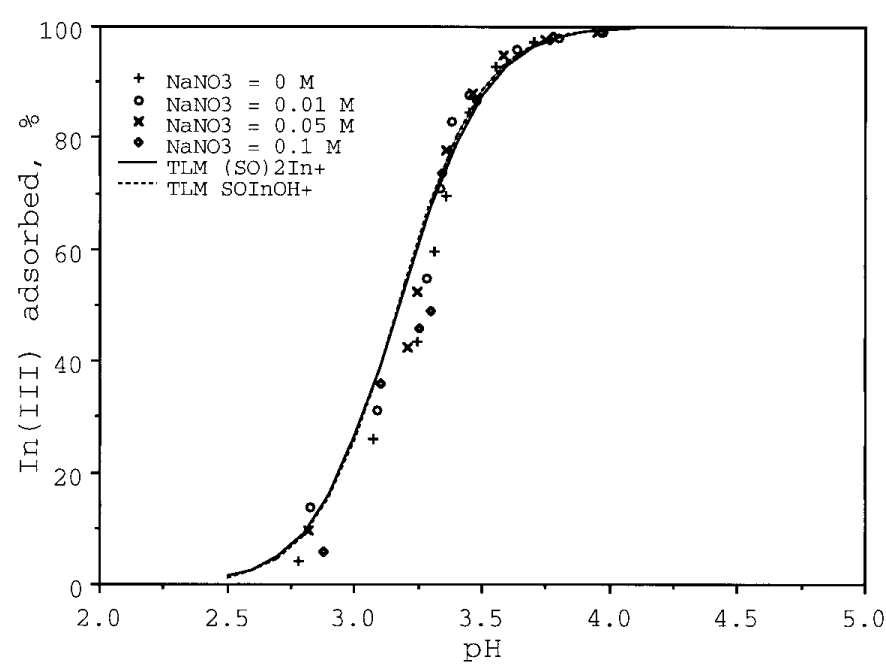

FIG . 2. Adsorption of $\mathrm{In}(\mathrm{III})$ onto $\gamma-\mathrm{Al}_{2} \mathrm{O}_{3}$ as a function of $\mathrm{pH}$ under various background $\mathrm{NaNO}_{3}$ concentrations. Solid lines denote TLM results with no $\mathrm{NaNO}_{3}$ addition using bidentate $(\mathrm{SO})_{2} \mathrm{In}^{+}$of Eq. [8]. Dotted line represents the simulation of monodentate $\mathrm{SOInOH}^{+}$using Eq. [9]. Symbols denote experimental data. 
TABLE 2

First Hydrolysis Constant and the pH Adsorption Range of $\mathrm{Ga}(\mathrm{III}), \mathrm{In}(\mathrm{III})$, and $\mathrm{Cr}(\mathrm{III})$

\begin{tabular}{ccc}
\hline $\begin{array}{c}\text { Trivalent } \\
\text { metal }\end{array}$ & $\mathrm{p} K_{\text {I }}^{*}$ & $\begin{array}{c}\mathrm{pH} \text { adsorption } \\
\text { range }\end{array}$ \\
\hline $\mathrm{Ga}(\mathrm{III})$ & $2.6^{a}$ & $1.5-3.2$ \\
$\mathrm{In}(\mathrm{III})$ & $3.9^{a}$ & $2.8-4.0$ \\
$\mathrm{Cr}(\mathrm{III})$ & $4.1^{a}$ & $3.2-4.5^{b}$ \\
\hline
\end{tabular}

${ }^{a}$ Baes and Mesmer (18).

${ }^{b}$ Chang et al. (12).

$\mathrm{pH}$-adsorption curves. Conversely, formation of innersphere complexes as proposed in Eqs. [7]-[10] of TLM was able to fit the experimental data with no $\mathrm{NaNO}_{3}$ addition. Specifically the model was able to fit the data quite well with the formation of the monodentate complex $\mathrm{SOGa}^{2+}$ or $\mathrm{SOIn}^{2+}$ (figure not shown) and the bidentate complex $(\mathrm{SO})_{2} \mathrm{Ga}^{+}\left[(\mathrm{SO})_{2} \mathrm{In}^{+}\right]$as shown in Figs. 1 and 2 . As the major $\mathrm{Ga}(\mathrm{III})$ and $\mathrm{In}(\mathrm{III})$ species over the adsorption $\mathrm{pH}$ range are $\mathrm{Ga}^{3+} / \mathrm{In}^{3+}$ and $\mathrm{GaOH}^{2+} / \mathrm{InOH}^{2+}$, the formation of monodentate $\mathrm{SOGaOH}^{+}\left[\mathrm{SOInOH}^{+}\right]$and bidentate $\left.(\mathrm{SO})_{2} \mathrm{GaOH}\left[(\mathrm{SO})_{2} \mathrm{InOH}\right)\right]$ was also simulated. The results were also able to fit the experimental data quite well [Fig. $1\left(\mathrm{SOGaOH}^{+}\right)$and Fig. $\left.2\left(\mathrm{SOInOH}^{+}\right)\right]$. The intrinsic formation constants for the mono- and bidentate $\mathrm{Ga}(\mathrm{III})$ and In(III) surface complexes are summarized in Table 3.

The study on $\mathrm{Cr}$ (III) adsorption by Chang et al. (12) has suggested that the dominant surface species are $\mathrm{Cr}^{3+}$ and $\mathrm{CrOH}^{2+}$, while Wehril et al. (11) report surface $\mathrm{CrOH}^{2+}$ species. In the acid/base titration experiments, the calculated number of protons released per $\mathrm{Ga}$ (III) or In(III) sorbed is about two (mole basis); for comparison, Wehril et al. (11) report slightly more than two protons released per $\mathrm{Cr}$ (III) adsorbed onto aluminum oxide. These results may indicate that the formation of monodentate $\mathrm{GaOH}^{2+} / \mathrm{InOH}^{2+}$ and bidentate $\mathrm{Ga}^{3+} / \mathrm{In}^{3+}$ is most likely surface complexes. Indeed, the hypothesis was further verified with the kinetic results using the pressure-jump technique.

TABLE 3

TLM Optimized Intrinsic Formation Constants of Monodentate and Bidentate $\mathrm{Ga}(\mathrm{III}) / \mathrm{In}(\mathrm{III})$ Surface Complexes

\begin{tabular}{lc}
\hline Surface complex & $\log * K^{\text {int }}$ \\
\hline $\mathrm{SOGa}^{2+}$ & 10.3 \\
$(\mathrm{SO})_{2} \mathrm{Ga}^{+}$ & 3.15 \\
$\mathrm{SOGaOH}$ & 1.73 \\
$(\mathrm{SO})_{2} \mathrm{GaOH}^{2+}$ & -5.21 \\
$\mathrm{SOIn}{ }^{2+}$ & 8.87 \\
$(\mathrm{SO})_{2} \mathrm{In}^{+}$ & 1.63 \\
$\mathrm{SOInOH}$ & 0.26 \\
$(\mathrm{SO})_{2} \mathrm{InOH}^{+}$ & -6.67 \\
\hline
\end{tabular}
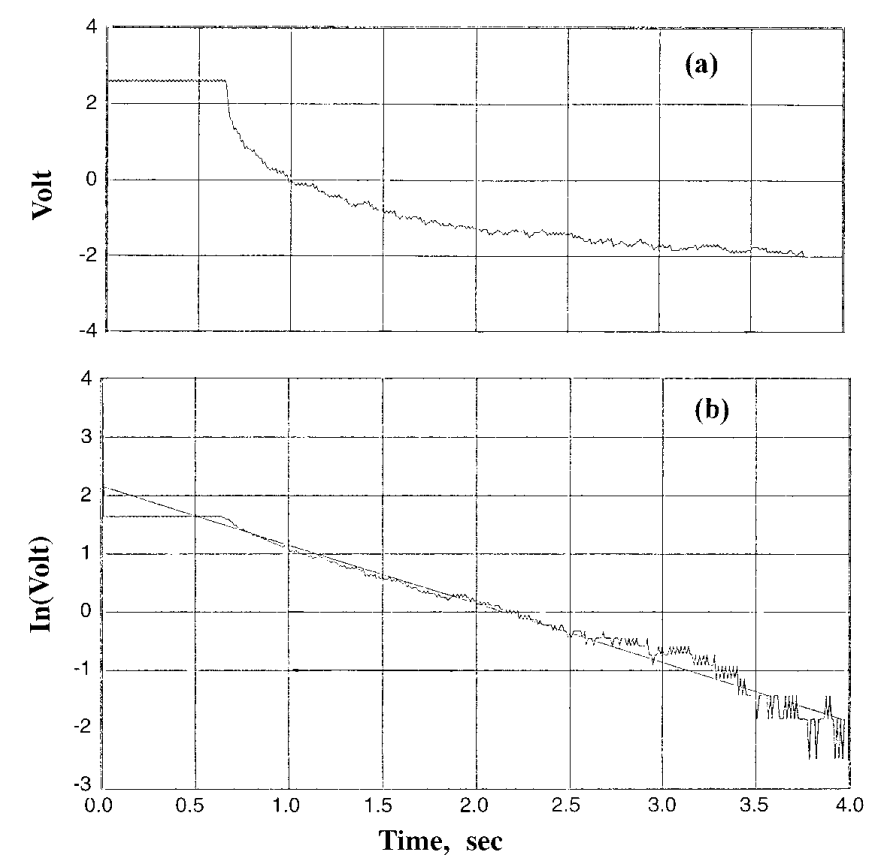

FIG. 3. (a) Typical relaxation curve in $\mathrm{Ga}(\mathrm{III}) / \gamma-\mathrm{Al}_{2} \mathrm{O}_{3}$ system by pressure-jump technique. (b) Semi-logarithmic plot of typical relaxation curve.

\section{Kinetics}

A typical relaxation curve for the $\mathrm{Ga}(\mathrm{III}) / \gamma-\mathrm{Al}_{2} \mathrm{O}_{3}$ suspension is shown in Fig. 3a. Similar relaxation curves were also observed for the $\mathrm{In}(\mathrm{III}) / \gamma-\mathrm{Al}_{2} \mathrm{O}_{3}$ suspension. The $\tau^{-1}$ was obtained from the natural logarithmic plot of the electrical potential versus time (Fig. 3b). Systems containing $\mathrm{Ga}\left(\mathrm{NO}_{3}\right)_{3}$ or $\operatorname{In}\left(\mathrm{NO}_{3}\right)_{3} \cdot 3 \mathrm{H}_{2} \mathrm{O}$ only and the supernatant of the suspension of $\gamma-\mathrm{Al}_{2} \mathrm{O}_{3}$ were also subjected to the pressure-jump test. No relaxation was noticed in either of these systems, demonstrating that relaxation can be attributed solely to the association/dissociation of $\mathrm{Ga}$ (III)/In(III) at the water $/ \gamma-\mathrm{Al}_{2} \mathrm{O}_{3}$ interface.

Proposed reaction pathways in the Ga(III) or In(III) $/ \gamma$ $\mathrm{Al}_{2} \mathrm{O}_{3}$ system are presented in Table 4. Mechanisms I and II in Table 4 represent the mechanistic pathway proposed by others $(5,7)$ in which the sorbed metal ion is associated with surface hydroxyl site(s) followed by the detachment of proton(s). Other possible mechanistic pathways for the adsorption processes were formulated as proton release from surface hydroxyl group(s) followed by attachment of $\mathrm{Ga}(\mathrm{III}) / \mathrm{In}$ (III) species as shown in mechanisms III and IV which are analogous to the $\mathrm{S}_{\mathrm{N}} 1$ mechanism (substitution nucleophilic unimolecular) (16).

To examine the plausibility of the proposed adsorption mechanisms, the corresponding reciprocal relaxation time constants were derived as a function of the reactant and product concentrations $(\{\mathrm{MI} *\},\{\mathrm{MII} *\},\{\mathrm{MIII} *\}$, and $\left\{\right.$ MIV $\left.^{*}\right\}$, Table 4$)$ for the postulated mechanisms. If a plot of $\tau^{-1}$ measured from the pressure-jump experi- 
TABLE 4

Possible Mechanistic Pathways and the Relationship between Reciprocal Relaxation Times and $\mathrm{C}$ oncentrations of $\mathrm{Ga}(\mathrm{III}) / \mathrm{In}(\mathrm{III})$ Species on a $\gamma-\mathrm{Al}_{2} \mathrm{O}_{3}$ Surface

Mechanism I

(1) Mechanistic pathway

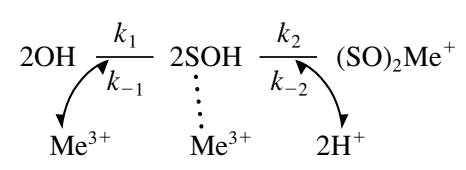

(2) Relationship between reciprocal relaxation times and species activities

$$
\begin{gathered}
\tau^{-1}=k_{1}^{\text {int }}\left\{\exp \left(\frac{-3 \psi_{0} F}{2 R T}\right)\left(\overline{[\mathrm{SOH}]^{2}}+\overline{[\mathrm{SOH}]} \overline{\left\{\mathrm{Me}^{3+}\right\}}\right)+\frac{1}{K^{\text {int }}} \exp \left(\frac{-\psi_{0} F}{2 R T}\right)\left(\overline{\left[(\mathrm{SO})_{2} \mathrm{Me}^{+}\right]} \overline{\left\{\mathrm{H}^{+}\right\}}+\overline{\left\{\mathrm{H}^{+}\right]^{2}}\right)\right\}=k_{1}^{\text {int }}\left\{\mathrm{MI}^{*}\right\} \\
\text { Mechanism II }
\end{gathered}
$$

(1) Mechanistic pathway

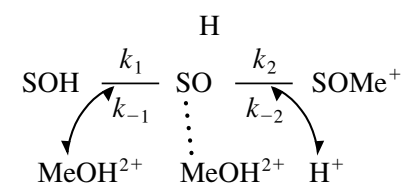

(2) Relationship between reciprocal relaxation times and species activities

$$
\tau^{-1}=k_{1}^{\text {int }}\left\{\exp \left(\frac{-\psi_{0} F}{R T}\right)\left(\overline{[\mathrm{SOH}]}+\overline{\left\{\mathrm{MeOH}^{2+}\right\}}\right)+\frac{1}{K^{\text {int }}}\left(\overline{\left[\mathrm{SOMeOH}^{+}\right]}+\overline{\left\{\mathrm{H}^{+}\right\}^{2}}\right)\right\}=k_{1}^{\text {int }}\left\{\mathrm{MII}^{*}\right\}
$$

Mechanism III

(1) Mechanistic pathway

$$
2 \mathrm{OH} \frac{k_{1}}{k_{-1}} \underbrace{2 \mathrm{SO}^{-}}_{2 \mathrm{H}^{+}} \frac{k_{2}}{\mathrm{Me}_{k_{-2}}}(\mathrm{SO})_{2} \mathrm{Me}^{+}
$$

(2) Relationship between reciprocal relaxation times and species activities

$$
\begin{gathered}
\tau^{-1} \exp \left(\frac{-3 \psi_{0} F}{2 R T}\right)=k_{2}^{\mathrm{int}}\left\{\exp \left(\frac{-3 \psi_{0} F}{R T}\right)\left(\overline{\left[\mathrm{SO}^{-}\right]^{2}}+\frac{\overline{\left[\mathrm{SO}^{-}\right]} \overline{\left\{\mathrm{Me}^{3+}\right\}}}{\mathrm{G}}\right)\right\}+k_{-2}^{\mathrm{int}}=k_{2}^{\mathrm{int}}\left\{\mathrm{MIII}^{*}\right\}+k_{-2}^{\mathrm{int}} \\
\text { with } \\
G=\frac{\overline{\left\{\mathrm{H}^{+}\right\}^{2}} \overline{\left[\mathrm{SO}^{-}\right]}}{\left(K_{\mathrm{a} 2}^{\mathrm{int}}\right)^{2} \exp \left(2 \psi_{0} F / R T\right) \overline{\mathrm{SOH}]}+\overline{\left\{\mathrm{H}^{+}\right\}} \overline{\left[\mathrm{SO}^{-}\right]^{2}}+1} \\
\text { Mechanism IV } \\
\text { (1) Mechanistic pathway }
\end{gathered}
$$

$$
\mathrm{SOH} \frac{k_{1}}{k_{-1}} \underbrace{}_{\mathrm{H}^{+}} \mathrm{SO}_{\mathrm{MeOH}^{-}} \frac{k_{2}}{k_{-2}} \mathrm{SOMeH}^{+}
$$

(2) Relationship between reciprocal relaxation times and species activities

$$
\tau^{-1} \exp \left(\frac{-\psi_{0} F}{R T}\right)=k_{2}^{\mathrm{int}}\left\{\exp \left(\frac{-2 \psi_{0} F}{R T}\right)\left(\overline{\left[\mathrm{SO}^{-}\right]}+\overline{\left\{\mathrm{MeOH}^{2+}\right\}} \frac{\left(K_{\mathrm{a} 2}^{\mathrm{int}}\right) \exp \left(\psi_{0} F / R T\right)+\overline{\left[\mathrm{SO}^{-}\right]}}{\left(K_{\mathrm{a} 2}^{\mathrm{in}}\right) \exp \left(\psi_{0} F / R T\right)+\overline{\left\{\mathrm{H}^{+}\right\}} \overline{\left[\mathrm{SO}^{-}\right]}}\right)\right\}+k_{-2}^{\mathrm{int}}=k_{2}^{\mathrm{int}}\left\{\mathrm{MIV}^{*}\right\}+k_{-2}^{\mathrm{int}}
$$

Note. Me denotes Ga or In. 
TABLE 5

The Intrinsic Rate Constants and Equilibrium Constants in Mechanism III and IV

\begin{tabular}{ccccc}
\hline Mechanism & $\begin{array}{c}\log * k_{2}^{\text {int }} \\
\left(\mathrm{L} \mathrm{mol}^{-1} \mathrm{~s}^{-1}\right)\end{array}$ & $\begin{array}{c}\log * k_{-2}^{\text {int }} \\
\left(\mathrm{s}^{-1}\right)\end{array}$ & $\begin{array}{c}\log * K_{2, \text { kinetic }}^{\text {int }} \\
\left(\mathrm{L} \mathrm{mol}^{-1}\right)\end{array}$ & $\begin{array}{c}\log * K_{2, \text { equili }}^{\text {int }} \\
\left(\mathrm{L} \mathrm{mol}^{-1}\right)\end{array}$ \\
\hline Ga & & & & \\
III & 13.22 & -8.92 & 22.13 & 22.15 \\
IV & 8.04 & -6.39 & 14.43 & 13.83 \\
In & & & & \\
III & 12.83 & -8.96 & 21.34 & 20.63 \\
IV & 7.44 & -8.06 & 15.49 & 13.76 \\
\hline
\end{tabular}

ments against the corresponding " $\left\{M^{*}\right\}$ ', function calculated from the TLM is linear, the hypothesized mechanism is consistent with the data. The intrinsic reaction rate constants are then determined from the slope and/ or intercept of such a plot. As a result, mechanisms I and II (the Hachiya mechanism) were ruled out, since the corresponding plots were not linear.

Plots of experimentally determined $\tau^{-1}$ values versus $\{$ MIII* $\}$ and $\left\{\mathrm{MIV}^{*}\right\}$ were linear (Figs. 4 and 5 for $\mathrm{Ga}(\mathrm{III}) / \gamma-\mathrm{Al}_{2} \mathrm{O}_{3}$; Figs. 6 and 7 for $\mathrm{In}(\mathrm{III}) / \gamma-\mathrm{Al}_{2} \mathrm{O}_{3}$ ), and the slopes and intercepts of the straight lines were used to compute the forward and reverse rate constants of relevant reactions. The intrinsic adsorption equilibrium constants calculated from the kinetic experiments (i.e., the ratio of the forward and reverse reaction rate constants) and the equilibrium constants simulated from the TLM are listed in Table 5 for comparison. These constant values obtained from kinetic experiments (for $(\mathrm{SO})_{2} \mathrm{Ga}^{+}$ $\left[(\mathrm{SO})_{2} \mathrm{In}^{+}\right]$, and $\mathrm{SOGaOH}^{+}\left[\mathrm{SOInOH}^{+}\right]$species $)$are in good agreement with those from equilibrium and the TLM work, indicating that mechanisms III and IV are

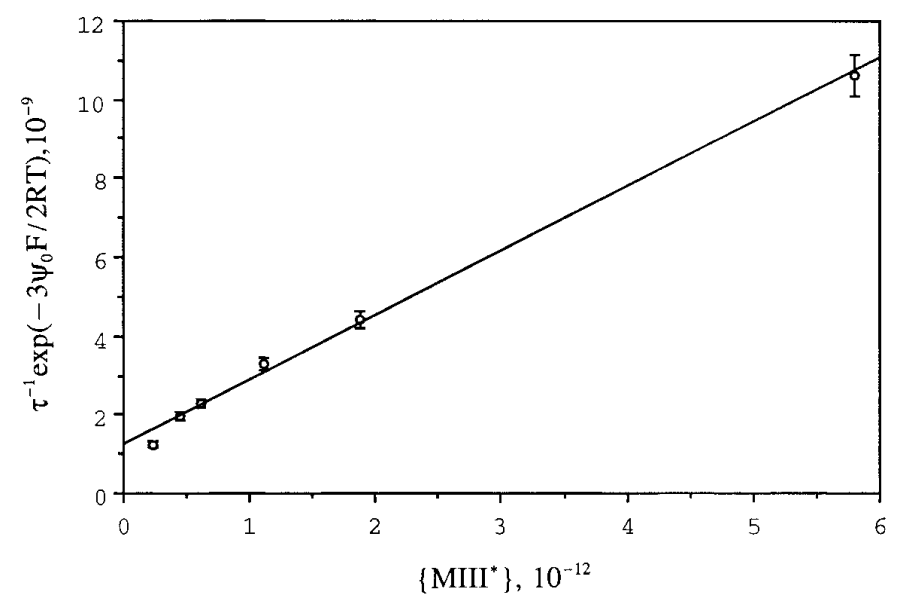

FIG. 4. Plot of $\tau^{-1} \exp \left(-3 \psi_{0} F / 2 R T\right)$ vs $\{$ MIII* $\}$ in Eq. [16]. The concentrations of $\mathrm{Ga}$ (III) species were calculated based on the optimized intrinsic formation constants.

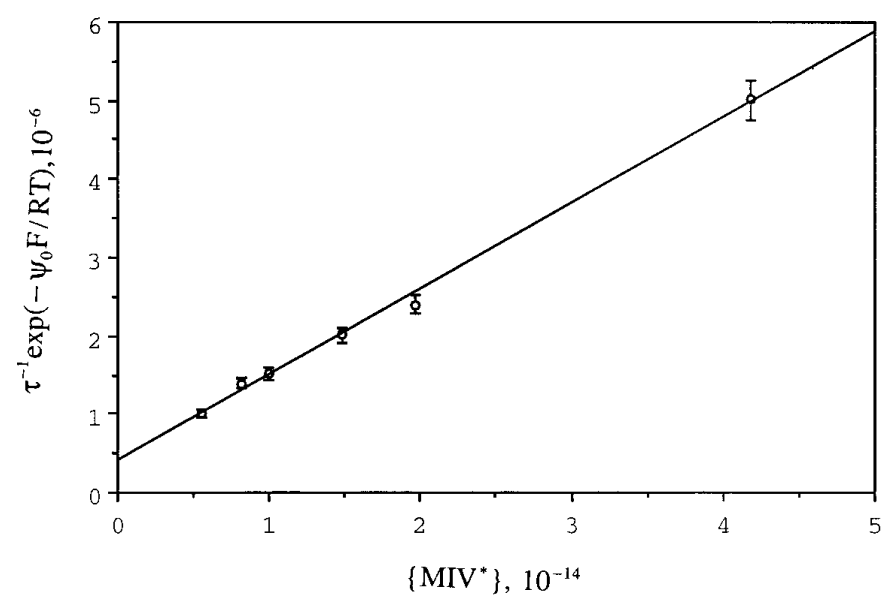

FIG. 5. Plot of $\tau^{-1} \exp \left(-\psi_{0} F / R T\right)$ vs $\left\{\mathrm{MIV}^{*}\right\}$ in Eq. [18]. The concentrations of $\mathrm{Ga}(\mathrm{III})$ species were calculated based on the optimized intrinsic formation constants.

reasonable models for the reactions in the $\mathrm{Ga}(\mathrm{III}) /$ or $\mathrm{In}(\mathrm{III}) / \gamma-\mathrm{Al}_{2} \mathrm{O}_{3}$ system.

Hachiya et al. (7) applied the pressure-jump technique to study the adsorption mechanism of $\mathrm{Pb}^{2+}, \mathrm{Cu}^{2+}, \mathrm{Zn}^{2+}, \mathrm{Co}^{2+}$, and $\mathrm{Mn}^{2+}$ and reported that the adsorption of divalent metal ions exhibited the dissociative mechanism. The sorption process is stated as a two-step ligand exchange reaction in which the hydrated metal ion exchanges with the proton on oxide surface. In the first step, the hydrated metal ion losses one water molecular before it can attach to the surface hydroxyl reacting site. Thereafter, a proton is released to be substituted by the hydrated metal (Fig. 8a). As the surface reacting group does not affect the exchange rate, the reaction ratelimiting step might be closely correlated to the dissociation of hydrated water, i.e., the water exchange rate $\left(k_{\mathrm{H} 2 \mathrm{O}}\right)$. The LFER between the intrinsic adsorption rate constant, $k_{\mathrm{ads}(\mathrm{int})}$,

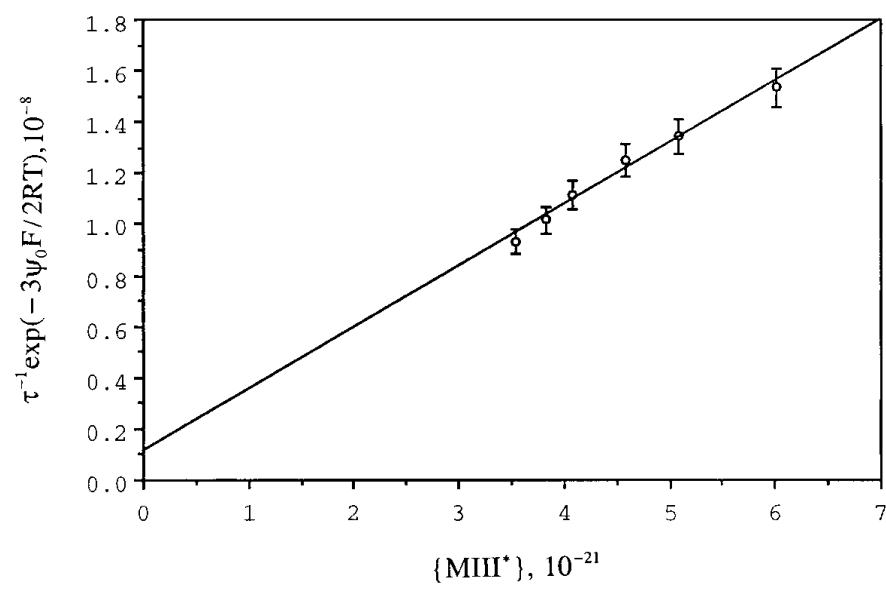

FIG. 6. Plot of $\tau^{-1} \exp \left(-3 \psi_{0} F / 2 R T\right)$ vs $\{$ MIII* $\}$ in Eq. [16]. The concentrations of In(III) species were calculated based on the optimized intrinsic formation constants. 


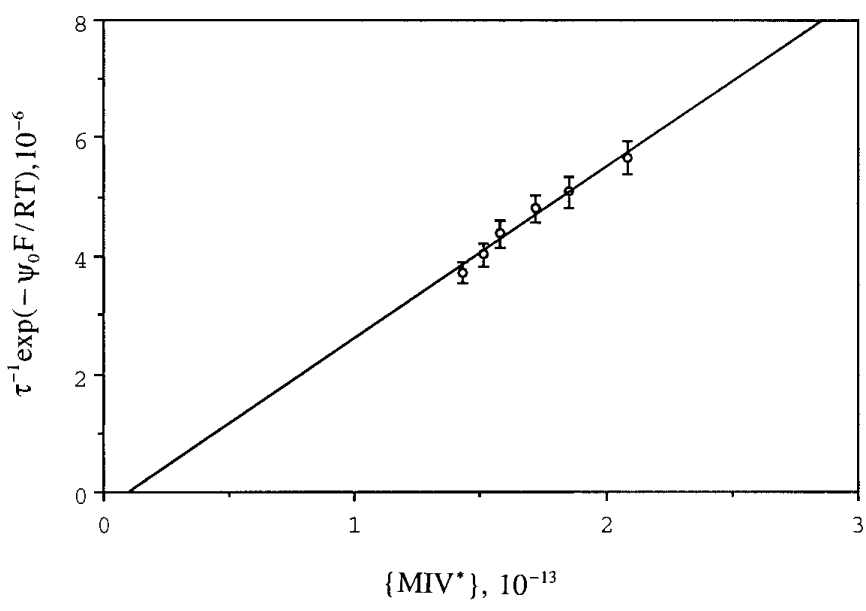

FIG. 7. Plot of $\tau^{-1} \exp \left(-\psi_{0} F / R T\right)$ vs $\left\{\mathrm{MIV}^{*}\right\}$ in Eq. [18]. The concentrations of In(III) species were calculated based on the optimized intrinsic formation constants.

and $k_{\mathrm{H} 2 \mathrm{O}}$ is $\log k_{\text {ads(int) }}=-4.16+0.92 \log k_{\mathrm{H} 2 \mathrm{O}}$. Stumm (17) also notes that trivalent ions of $\mathrm{Fe}^{3+}$ and $\mathrm{Al}^{3+}$ follow this relationship. By substituting the water exchange rates of $\mathrm{Ga}^{3+}$ and $\mathrm{In}^{3+}\left(7.6 \times 10^{2}\right.$ and $\left.4.0 \times 10^{4}(18)\right)$ into the above equation, it is found that there exists a discrepancy between the estimated $k_{\text {ads(int) }}$ and the pressure-jump determined values.

Wehril et al. (11) proposed that $\mathrm{Cr}^{3+}$ sorption was an associative mechanism and also noted that the adsorption rate constant was not comparable to that estimated by
LFER. In our recent work (12), the adsorption pathway of $\mathrm{Cr}(\mathrm{III}) / \gamma-\mathrm{Al}_{2} \mathrm{O}_{3}$ was different from that proposed by Hachiya et al. (7) and Wehril et al. (11). Although $\mathrm{Cr}(\mathrm{III})$ sorption is an associative process, Chang et al. (12) interpreted that a proton is released from surface hydroxyl group ( $\mathrm{s}$ ) followed by the attachment of $\mathrm{Cr}$ (III) species. The results of the present study essentially present the similar adsorption mechanisms of trivalent $\mathrm{Ga}$ and In ions onto $\gamma-\mathrm{Al}_{2} \mathrm{O}_{3}$ (Fig. 8b). Thus, the hydrated water interactions with the cation and surface sites are more rapid than those of the adsorption reaction and, as a result, hydration rate evaluation is not possible.

\section{CONCLUSIONS}

Kinetic investigation of $\mathrm{Ga}(\mathrm{III})$ and In(III) sorption on $\gamma-\mathrm{Al}_{2} \mathrm{O}_{3}$ indicates that the adsorption pathway of trivalent ions is a two-step mechanism: proton release from surface hydroxyl group(s) followed by coordination of $\mathrm{Ga}$ (III)/In (III) species to the depronated site (s). Formation of monodentate $\mathrm{SOGaOH}^{+} / \mathrm{SOInOH}^{+}$and bidentate $(\mathrm{SO})_{2} \mathrm{Ga}^{+} /(\mathrm{SO})_{2} \mathrm{In}^{+}$are the likely surface complexes which were verified by the pressure-jump results. The intrinsic adsorption rate constants for the $\mathrm{Ga}$ (III) and In(III) species were determined kinetically. The sorption of trivalent metal ions is an associative processes; therefore it is not possible to estimate the sorption rate constant with the LFER which is appropriate only for divalent metal ions.

(a) Divalent metal ion

Step 1

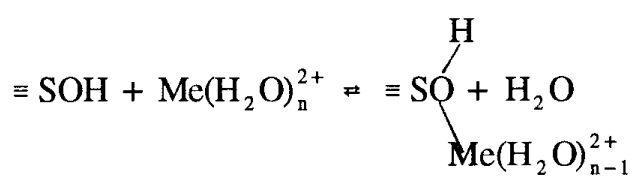

Step 2

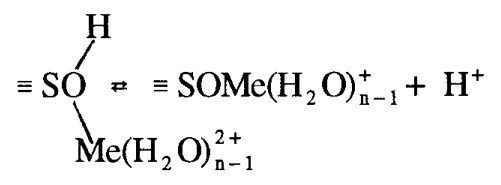

(b) Trivalent metal ion

$$
\begin{array}{ll}
\text { Step } 1 & \equiv \mathrm{SOH}+\mathrm{Me}\left(\mathrm{H}_{2} \mathrm{O}\right)_{\mathrm{n}}^{3+} \equiv \equiv \mathrm{SO}^{-}-\mathrm{Me}\left(\mathrm{H}_{2} \mathrm{O}\right)_{\mathrm{n}}^{3+}+\mathrm{H}^{+} \\
\text {Step 2 } & \equiv \mathrm{SO}^{-}-\mathrm{Me}\left(\mathrm{H}_{2} \mathrm{O}\right)_{\mathrm{n}}^{3+} \equiv \equiv \mathrm{SOMe}\left(\mathrm{H}_{2} \mathrm{O}\right)_{\mathrm{n}-1}^{2+}+\mathrm{H}_{2} \mathrm{O}
\end{array}
$$

FIG. 8. Sorption mechanism of (a) divalent and (b) trivalent metal ions. 


\section{ACKNOWLEDGMENT}

Funding for this research was provided by the National Science Council of the Republic of China under Grant NSC 83-0410-E-002-082.

\section{REFERENCES}

1. Huang, C. P., and Stumm, W., J. Colloid Interface Sci. 34, 409 (1973).

2. Benjamin, M. M., Environ. Sci. Technol. 17, 686 (1983).

3. Stumm, W., Huang, C. P., and Jenkins, S. R., Croat. Chem. Acta 42, 223 (1970).

4. Davis, J. A., and Leckie, J. O., J. Colloid Interface Sci. 67, 90 (1978).

5. Hayes, K. F., and Leckie, J. O., J. Colloid Interface Sci. 115, 564 (1987).

6. Hachiya, K., Ashida, M., Sasaki, M., Kan, H., Inoue, T., and Yasunaga, T., J. Phys. Chem. 83, 1866 (1979).

7. Hachiya, K., Sasaki, M., Saruta, Y., Mikami, N., and Yasunaga, T., J. Phys. Chem. 88, 23 (1984).
8. Zhang, P. C., and Sparks, D. L., Soil Sci. Am. J. 53, 1028 (1989).

9. Zhang, P. C., and Sparks, D. L., Environ. Sci. Technol. 24, 1848 (1990).

10. Zhang, P. C., and Sparks, D. L., Soil Sci. Am. J. 54, 1266 (1990).

11. Wehrli, B., Ibric, S., and Stumm, W., Colloids Surf. 51, 77 (1990).

12. Chang, K-S., Lin, C-F., Lee, D-Y., Lo, S-L., and Yasunaga, T., J. Colloid Interface Sci. 165, 169 (1994).

13. Hohl, H., and Stumm, W., J. Colloid Interface Sci. 55, 281 (1976).

14. Peri, J. B., J. Phys. Chem. 69, 211 (1965).

15. Hayes, K. F., Redden, G., Ela, W., and Leckie, J. O., J. Colloid Interface Sci. 142, 448 (1991).

16. March, J., “Advanced Organic Chemistry: Reactions, Mechanism, and Structure.' McGraw-Hill, New York, 1968.

17. Stumm, W., "Chemistry of the Solid-Water Interface.', Wiley, New York, 1992.

18. Martell, A. E., "Coordination Chemistry." American Chemical Society Monograph, Am. Chem. Soc., Washington, D.C., 1978; Baes, C. F., and Mesmer, J. R. E., ' 'The Hydrolysis of Cations.' Wiley, New York, 1976. 